\title{
Reorientasi Kurikulum dan Pembelajaran Pendidikan Agama Islam Pada Era Disrupsi T eknologi
}

\author{
Anwar Rosadi \\ Pascasarjana UIN Sunan Gunung Djati, Bandung, Indonesia \\ anwarrosadi1993@gmail.com \\ M ohamad Erihadiana \\ Pascasarjana UIN Sunan Gunung D jati, Bandung, Indonesia \\ erihadiana@uinsgd.ac.id
}

\begin{abstract}
The era of technological disruption is one of the characteristics and challenges of human life and civilization in the 21st century. So that it has an impact on the urgency of reorienting the curriculum and learning of Islamic Religious Education. The purpose of this study is to reveal the challenges, facts and phenomena of curriculum disorientation and learning in Islamic Religious Education. The research method in this article uses a qualitative approach to library research, which is descriptive and radical in which the researcher describes and explores the topic of program reorientation or curriculum formulation and learning of Islamic religious education which is full of challenges during this technological disruption. The results of this study are the need to strengthen and formulate Islamic Religious Education curriculum and learning that focuses on strengthening the goal of fostering human beings and affirming two human dimensions as caliph fil ard and Abdullah. As well as the need for the formulation and embodiment of curriculum and learning that trains the critical power of the nation's generation.
\end{abstract}

Keywords: Reorientation, curriculum, learning, PAI, disruption 


\begin{abstract}
Abstrak
Era distrupsi teknologi menjadi salah satu ciri serta tantangan kehidupan dan peradaban manusia pada abad-21. Sehingga berdampak pada urgensi reorientasi dari kurikulum dan pembelajaran Pendidikan Agama Islam. T ujuan penelitian ini yaitu untuk mengungkap tantangan, fakta dan fenomena disorientasi kurikulum dan pembelajaran Pendidikan Agama Islam. M etode penelitian dalam artikel ini yaitu menggunakan pendekatan kualitatif jenis library research yaitu bersifat deskriptif serta radikal di mana peneliti menggambarkan dan mengeksplorasi topik tentang reorientasi program atau rumusan kurikulum dan pembelajaran Pendidikan agama Islam yang penuh tantangan pada masa distrupsi teknologi ini. Hasil dari penelitian ini yaitu, perlunya memperkuat serta merumuskan kurikulum dan pembelajaran Pendidikan Agama Islam yang berfokus pada penguatan Tujuan yakni membina insan kamil serta mempertegas dua dimensi manusia sebagai khalifah fil ard dan Abdullah. Serta perlunya perumusan dan pengejawantahan kurikulum dan pembelajaran yang melatih daya kritis generasi bangsa.
\end{abstract}

Kata kunci: Reorientasi, kurikulum, pembelajaran, PAI, distrupsi

\title{
A. Pendahuluan
}

Validitas dunia pendidikan sekarang sedang menjadi tandatanya besar, karena pendidikan yang diimplementasikan sekarang belum memberikan kontribusi nyata dalam peningkatan mutu karakter bagi lulusannya, terlebih muncul berbagai kritik tajam yang ditujukan kepadanya, sehingga muncul berbagai spekulasi penyelesaian yang justru tidak mampu menyelesaikan akar persoalannya. $\mathrm{H}$ al ini dilihat dengan semakin banyaknya prilaku lulusan pendidikan "oknum" yang mencoreng dunia pendidikan, rentetan kritik tersebut tak akan pernah berhenti mengusik dunia pendidikan, termasuk pendidikan Islam di Indonesia.

Banyak faktor yang menyebabkan terjadinya gravitasi terhadap pendidikan Islam di Indonesia seperti cultural lag. Penetrasi teknologi informasi menyebabkan perubahan sosial yang cukup cepat bahkan tidak terkendali, sedangkan laju pendidikan melaju dengan kecepatan yang super lambat dengan seabreg kurikulum yanag tidak pernah jelas -selalu berubah- baik kebijakan dan kontennya. 
Pertama dalam sejarah, dunia sekolah diisi empat generasi sekaligus. Generasi kertaspensil, generasi komputer, generasi internet dan generasi smartphone hal itu menyebabkan kesenjangan antar generasi (Kasali, 2020: 16). Problem dunia pendidikan seperti fasilitas teknologi lembaga pendididkan yang dimiliki belum merata, jaringan internet yang jauh dari kata merata, belum lagi persoalan listrik. M isalnya sebuah lembaga baru memiliki mesin ketik kini sudah muncul komputer dan LCD, kemudian muncul internet dan smartphone hingga sampai sekarang yakni munculnya robot-robot yang akan membantu tugas manusia sebagai indikasi dari lahirnya kecerdasan buatan serta internet of things, hal itu menyebabkan perbedaan kemampuan antar generasi yang jelas menjadi celah ketersinggungan.

Dampak peralihan peran tersebut menjadikan peran guru senior dan junior sebagai agen perubahan mempunyai karakteristik kemampuan yang sangat berbeda, penyebabnya adalah tidak adanya kesinambungan ilmu pengetahuan yang diperoleh -cara dan metodenyasehingga menyebabkan problem tersendiri antara guru senior dan guru junior. Penyebabnya adalah diambilalihnya ketersediaan informasi ilmu yang tanpa batas oleh internet atau smartphone.

Media dan metode pembelajaranpun semakin komplek seperti penggunaan teleconference dalam kegiatan pembelajaran tatap muka semakin mereduksi fungsi ruang kelas dan jam pelajaran, karena belajar dapat dilakukan dimana saja dan kapan saja sesuai gurunya, hal ini pula bias menyebabkan celah konflik baru terhadap perkembangan dunia pendidikan. Banyak contoh cultural lag antara kebudayaan material (teknologi) dengan kebudayaan nonmaterial (ilmu -pendidikan). Contoh cultural lag antar-kebudayaan non-material menjadi kritik yang sangat menohok dunia pendidikan seperti korupsi, LGBT, fenomena jihad, kejahatan anak dan lain sebagainya.

Faktor ketiga adalah fragmentasi. Pendidikan dalam amanat undang-undang nomor 20 tahun 2003 mengamanatkan dengan jelas akan kewajiban negara sebagai penyelenggara penididikan, namun pada prakteknya masih ada sekat-sekat dalam pendidikan. Pendidikan 
yang dikelolah Negara dengan pendidikan yang dikelolah swasta terlihat sangat berbeda perlakuanya begitu juga antara pendidikan yang dikelolah kementerian pendidikan dengan yang dikelolah kementrian agama.

Dikotomi pendidikan antara pendidikan umum dan pendidikan Islam masih terjadi seperti dalam konteks disiplin ilmu. Fragmentasi dikotomi antara disiplin ilmu Islam dengan disiplin ilmu umum masih sering terjadi. Berbagai upaya sudah dijalankan untuk mewujudkan integrasi antar-disiplin ilmu, namun sekat dikotomi masih belum benar- benar hilang. Konteks politik pendidikan, kebijakan politik juga masih kentara seperti perbedaan kebijakan pendidikan antara Kementrian Pendidikan dan Kebudayaan dengan Kementrian Agama, kebijakan Direktorat Pendidikan Tinggi dengan Direktorat Pendidikan Tinggi Islam kerap memicu polemik di dunia pendidikan, misalnya menyangkut gaji atau sertifikasi pendidik, pelaksanaan ujian nasional, lomba-lomba skala nasional dan lain sebagainya. Dinamika tersebut mengindikasikan adanya persoalan yang serius sedang dihadapi pendidikan khususnya pendidikan Islam di Indonesia. Artikel ini bermaksud menelaah permasalahan pendidikan Islam secara sistematis dalam dinamika pendidikan Islam tinjauan aspek metodologis, akademik dan kualitas.

Reorientasi dinamika pendidikan A gama Islam mempunyai hikmah- hikmah tersendiri dalam merealisir kemaslahatan umat manusia baik dengan cara mendatangkan manfaat maupun menampik mafsadat. Disinilah fungsi pendidikan Islam diharapkan untuk mampu memberikan solusi nyata bagi pendidikan di Indonesia. Pentingnya dilakukan penelitian dalam pendidikan Islam sebagai visi dalam ruh pendidikan setidaknya mempunyai beberapa alasan dilihat dari sudut pandang esoteris sharî́ah Islam, problem utama pada nuansa familier dan dinamis ketika bersinggungan dengan unsur-unsur yang secara eksoteris. Bagaimana reorientasi dinamika pendidikan Islam yang bersifat fleksibel-dinamis, dapat menampung berbagai perkembangan terkini, mengantarkan pada kemaslahatan alam semesta yang menjadi tujuan Islam rahmat li al-âlamîn. Seperti contoh teori Multiple Intelligences dalam sudut pandang I slam tidak tertulis, tapi tersirat sebagai tujuan penting pendidikan dari sisi hifz al-'aql atau memaksimalkan fungsi akal untuk tujuan memelihara dan mengembangkan fungsi akal atau intelektual peserta didik. 
Totalitas kebutuhan hidup manusia merupakan alasan berikutya untuk menjadikan penelitian ini menjadi urgent untuk dijadikan sebagai acuan tujuan pendidikan. Seperti tujuan pendidikan nasional yang termaktub dalam undang-undang N 0.20 T ahun 2003.

“... mengembangkan potensi peserta didik agar menjadi manusia yang beriman dan bertakwa kepada Tuhan Yang Maha Esa, berakhlak mulia, sehat, berilmu, cakap, kreatif, mandiri, dan menjadi warga negara yang demokratis serta bertanggung jawab. Beriman, bertakwa dan berakhlak mulia masuk dalam fungsi hifz al-dîn, sehat dan bertanggung-jawab masuk dalam rana hifz al-nafs, berilmu, cakap dan kreatif tercover dalam hifz al-'aql, menjadi warga negara yang demokratis tujuan dalam hifz al-nas/ dan mandiri tercakup dalam hifz almâl."

Tujuan berikutnya adalah merepresentasikan dimensi Ilahi yang bersifat absolutpermanen (al-thaawâbit), sekaligus dimensi Insani yang bersifat relatif-temporer (almutaghayyirât). Pendidikan Islam hadir dalam setiap elemen pendidikan, tapi manifestasinya diharapkan selalu dinamis, sesuai konteks ruang dan waktu. Pendidikan Islam bertanggungjawab mengimplementasikan kompetensi hifz al-mâl supaya lulusan pendidikan Islam tumbuh menjadi pribadi yang mandiri, bukan menjadi beban bagi orang lain. Penerapan program pendidikannya bersifat dinamis sebagai bentuk lain dalam aplikasi keterampilan vokasional meliputi teknologi informasi dan komunikasi yang dibutuhkan oleh masyarakat kontemporer.

Pendekatan serta metode penelitian yang digunakan dalam eksplorasi ini bersifat deskriptif atau strategi yang bersifat radikal di mana peneliti perlu menggambarkan dan mengeksplorasi topik tentang reorientasi program atau rumusan kurikulum dan pembelajaran Pendidikan agama Islam yang penuh tantangan pada masa distrupsi teknologi ini. Eksplorasi deskriptif yang radikal tersebut, mencoba menggambarkan semua manifestasi atau kondisi sebagaimana adanya pada saat pemeriksaan sumber primer dan sekunder yang berkaitan dengan penelitian ini. Adapun sumber data dalam penelitian ini menggunakan buku dan jurnal terkait reorientasi kurikulum dan pembelajaran Pendidikan Agama Islam (Arikunto 2019, 14). Strategi pemilahan informasi dalam penelitian ini adalah studi Pustaka. Instrumen pada umumnya adalah analisis sendiri di mana peneliti akan menggunakan artikel yang termuat di jurnal atau buku harian, menginterpretasikan dan mencatat hasil dari penelitian dengan metode studi Pustaka. 


\section{B. Pembahasan}

\section{Kurikulum Pembelajaran}

Kurikulum didapat dari bahasa Yunani kuno, khususnya rencana pendidikan. Program pendidikan yang berasal dari kata curir yang berarti pelari cepat; dan Curere yang berarti tempat yang didorong (Purwadhi, 2019: 145). O leh karena itu, dari pengertian yang sempit, kurikulumm dapat diartikan sebagai jarak yang harus ditempuh oleh sprinter pada lintasan tertentu untuk mencapai tujuan tertentu. Dari makna etimologis definisi di atas, program pendidikan sejauh pengajaran umumnya diartikan sebagai contoh yang harus diambil oleh siswa di sekolah dalam suatu pelajaran tertentu untuk mencapai tujuan Pendidikan tertentu (Valerie, 2003: 21).

Kemudian, pada saat itu istilah rencana pendidikan kembali berkembang, kata program pendidikan atau kurikulum digunakan sebagai sejumlah (kursus) atau mata pelajaran yang harus ditempuh untuk mencapai gelar atau ijazah (M ahlail, 2019: 41). D engan cara ini, biasanya gagasan rencana pendidikan dicirikan sebagai mata pelajaran yang diajarkan di sekolah. Gagasan tentang rencana pendidikan yang dianggap konvensional masih dipahami dan dianut secara luas oleh banyak orang saat ini.

Sementara itu, untuk meningkatkan arti penting dari rencana Pendidikan atau kurikulum, istilah yang berbeda dapat diambil untuk memahami kurikulum dalam bahasa A rab. Kata rencana pendidikan pada umumnya dikomunikasikan dengan istilah manhaj yang berarti "jalan yang dilalui oleh orang-orang dalam berbagai bidang kehidupan" (Endang Widuri, 2012: 1). Sedangkan kurikulum instruktif (manhaj al-dirasah) dalam acuan kata Tarbiyah adalah sekumpulan rencana dan media yang digunakan sebagai acuan oleh organisasi edukatif dalam mencapai tujuan instruktif ( Saepudin A hmad Izzan, 2016: 34). Selain itu, arti kurikulum dalam kata-kata, banyak ahli mencirikan rencana pendidikan dengan cara yang berbeda, ada banyak kesamaan dalam pentingnya setiap definisi, kecuali ada perbedaan yang sangat mendasar yang dikomunikasikan dari definisi ini. Jelas perbedaan definisi yang ditunjukkan oleh pencipta ini memiliki dampak subordinat yang dapat beragam dalam penerapannya di lapangan. Hilda Taba yang dikutip oleh N ana Sukmadinata ( Sukmadinata, 1998: 3) Rencana pendidikan atau kurikulum adalah rencana pembelajaran yang disusun dengan mempertimbangkan berbagai hal yang berkaitan dengan sistem pembelajaran dan pergantian peristiwa serta interaksi individu.

Belajar adalah interaksi yang berfungsi bagi siswa untuk belajar dan memahami ide-ide yang diciptakan dalam instruksi dan latihan pembelajaran. Ukuran pengajaran dan 
pembelajaran adalah program kolaborasi korespondensi dinamis antara siswa siswa dengan pendidik dalam latihan instruktif. Dalam latihan belajar Dalam mengajar ada latihan yang dikerjakan siswa dan ada latihan yang diselesaikan pendidik yang terjadi secara sinergis. Sistem pembelajaran harus dicari dan terus menerus melekat pada suatu tujuan. Selanjutnya, semua asosiasi, teknik dan kondisi belajar harus diatur dan mengacu pada target ingin belajar (M ursidin, 2020: 23).

Secara etimologis pendidikam diubah menjadi bahasa Arab Tarbiyah dengan kata tindakan Rabba yang artinya memelihara, mengajar, mengikuti. Pendidikaan Aagama Isllam merupakan pelatihan dan pmbinaan yang diselesaikan secara metodis dalam mengarahkan anak-anak muda yang beragama Islam, sehingga pelajaran Islam benar-benar diketahui, diklaim, dan dipraktikkan oleh siswa baik tercermin dalam mentalitas, perilaku dan perspektif. M elalui ajaran Islam ada kursus untuk membentuk bagian dari karakter anak, khususnya sudut intelektual, penuh dengan perspektif perasaan dan sudut pandang psikomotorik. Dengan tujuan agar pelajaran Islam yang diandalkan menjadi bagian penting dari karakter anak muda. Karena secara keseluruhan latihan anak-anak akan mencerminkan watak Islami. Sistem persekolahan adalah siklus yang terus-menerus dimulai sejak seseorang dilahirkan ke dunia sampai ia gigit debu. Rincian lainnya adalah bahwa siklus instruktif menggabungkan kedua jenis pembelajaran formal dan kasual. Baik yang terjadi dalam iklim keluarga, kehidupan sekolah, pekerjaan maupun kehidupan daerah (Zakiyah D aradjat, 1996: 25).

\section{Distrupsi Teknologi}

Istilah Distrupsi mulai populer menjelang akhir abad kedua puluh di dunia bisnis, di mana organisasi besar mengal ami kesulitan karena imajinasi dan pengembangan dari organisasi kecil melalui organisasi terkomputerisasi. Ini melewati asumsi masa lalu. Pembusukan organisasi besar oleh organisasi kecil dalam persaingan bisnis disinggung sebagai Distrupsi (Christenssen, 1997: 97). Sejak saat itu, ungkapan "gangguan" sering menjadi titik fokus pertimbangan analis pasar, meskipun ungkapan "gangguan" sudah ada. Dengan perbaikan terkomputerisasi, organisasi baru berkembang, di mana organisasi kecil dapat mengungguli organisasi besar yang didirikan.

Pada awalnya, istilah Distrupsi masih menjadi isu yang menarik di kalangan analis keuangan, karena gangguan selalu dikaitkan dengan pengaturan bisnis, spekulasi, dan uang. Sesuai dengan kemajuan komputerisasi yang telah memasuki kehidupan manusia di berbagai bagian kehidupan manusia, hipotesis gangguan digunakan untuk menjelaskan berbagai perubahan besar dan penting dalam dunia bisnis, tetapi juga dalam berbagai masalah sehari- 
hari, khususnya persahabatan, sosial, dan politik. Interupsi menjadi instrumen yang masuk akal untuk memahami perkembangan yang terjadi karena peningkatan kemajuan dan imajinasi di mata publik. H ipotesis gangguan mengakui keadaan asli dunia dan masyarakat dalam periode inovasi data terkomputerisasi serta terotomatisasi ( 0 hitimur, 2018: 27).

Christensen mencirikan distrupsi teknologi sebagai munculnya inovasi yang gerakannya mengatur inovasi dan menggerakkan bisnis atau item yang kemudian melahirkan usaha baru (Ronda, 2019: 123). D istruspi teknologi bersifat destruktif dan kreatif. D estruktif, menyiratkan bahwa kemajuan lama dan korespondensi sudah ketinggalan zaman dan bahkan dapat membuat hambatan. A dapun kreatif berarti perkembangan kemajuan yang berbeda, baik di bidang inovasi dan pertukaran baru yang lebih produktif dan layak, yang mengarah ke praktik baru dalam moneter, sosial-sosial, politik, dan bagian lain dari keberadaan manusia termasuk berimplikasi dalam bidang K urikulum dan Pembelajaran Pendidikan Agama I slam.

\section{Disorientasi Kurikulum dan Pembelajaran Pendidikan Agama Islam}

Sudah dijelaskan sebelumnya bahwa distrupsi teknologi akan berdampak pada berbagai aspek kehidupan manusia. D alam hal ini terutama aspek kurikulum dan pembelajaran pendidkan Agama Islam yang mengalami disorientasi. Kurikulum dan pembelajaran PAI, terutama dalam era distrupsi teknologi ini, seharusnya diarahkan pada penguatan fungsi manusia sebagai $A$ bdullah ( $\mathrm{H}$ amba Allah SWT) serta tugas sebagai khalifah fil ard. $\mathrm{N}$ amun sayang, terjadi sebuah disorientasi yang nyata, dalam pembahasan sebagai berikut:

Dalam sistem pembelajaran, Penddidikan A gama Isllam secara praktis umumnya akan mendorong murid atau peserta didik untuk hanya memperoleh pengetahuan tentang Agama Islam, tanpa memerhatikan aspek implementasi dan implikasi pada akhlak al karimah. Akhirnya, materi Agama I slam berubah menjadi tujuan pembelajaran. Pendidik akan berusaha semaksimal mungkin untuk menyampaikan materi kepada siswa pada saat yang belum terlalu mapan. T ujuan pembelajaran menjadi sempiit, yakni Ketika siswa hanya mengetahui materi yang diberikan oleh pendidik di kelas. $\mathrm{H}$ al ini tentu sangat menyedihkan, karena Pembelajran Pendiidikan Agama Isllam tidak hanya untuk diketahui anak-anak, tetapi bagaimana perubahan perilaku pada anak-anak ini setelah mendapatkan pendidikan Agama Islam di sekolah.

Sebagaimana diungkapkan oleh M uhaimin ( M uhaimin, 2013: 56) bahwa Pendidikan Agama Islam, kurang siap untuk mengubah arah pencapaian pembelajaran yang kognitif oriented yakni cenderung pada penguasaan informasi atau pengutan ranah intelektual peserta didik menjadi petanda bahwa pembelajaran Pendiidikan Agama Isllam masih kurang memerhatikan aspek "nilai-nilai" atau value serta kurang meyakinkan ranah apeksi dan 
psikomotor peserta didik yyang harus terinternalisasikan dalam diri siswa atau peserta didik. M odel pembelajaran yang sering dilakukan oleh pengajar selama ini tentu saja akan cenderung ke arah tercapainya perubahan-perubahan sudut intelektual (ilmiah), yang diwujudkan melalui berbagai jenis model pembelajaran tertentu. Sementara itu, saya menemukan bahwa secara eksplisit pembelajaran PAI masih kurang menciptakan kapasitas penuh perasaan atau penghayatan serta internalisasi dan pengejawantahan materi Pendidiikan Agama Isllam tampaknya hampir tidak pernah dipertimbangkan dan diperhatikan oleh para perumus Kurikulum PAI dan terutama oleh ujung tombak Pendidikan yaitu Guru PAI itu sendiri Ketika melakukan pembelajaran di ruang $K$ ellas.

Menurut Penulis, kerapkali strategi pembelajaran di lembaga-lembaga pendidikan Islam masih berkutat pada empat aktivitas yang mengarah pada pembelajaran kognitif atau mengolah akal, yaitu: membaca, mendengar, melihat, dan mengucapkan. Sedangkan aktivitas yang menguatkan dimensi afektif dan psikomotor kurang disentuh. Sehingga perlu sebuah formulasi agar kesenjangan ini dapat terselesaikan.

Kemajuan inovasi membawa perubahan terhadap tuntutan eksistensi manusia. 0 rangorang mulai mengandalkan inovasi untuk menyelesaikan pekerjaan di berbagai bidang. Perubahan yang paling terlihat adalah pemanfaatan perangkat atau telepon genggam di kalangan masyarakat Indonesia sebagai sarana untuk korespondensi, sosial, hiburan, pembelajaran dan usaha peningkatan keuangan. Kemudahan mendapatkan perangkat akibat masa distrupsi teknologi untuk wilayah setempat telah memulai contoh lain komunikasi, lebih spesifiknya sebagai media berbasis web. M edia berbasis web adalah metode bagi seorang individu untuk dengan mudah memperoleh data yang berbeda melalui koneksi, korespondensi, usaha bersama, dan penawaran kepada orang lain pada dasarnya. Media online terus berkembang dan berdiferensiasi. M acam-macam media online tersebut antara lain: komunitas informal seperti: Facebook, T witter, Instagram, WhatsA pp, youtube, Zoom, LIN E, Songbird, Mi-Visit, yang sangat mudah dioperasikan melalui perangkat dan sering digunakan. Selanjutnya ada halaman web blog, jaringan online (diskusi) misalnya: kaskus.co.id, brainly.co.id, indowobster, dll. Keberadaan dan kemajuan teknologi ini, tentunya akan berdampak negatif dan positif.

Disrupsi teknologi ini, tentunya memiliki konsekuensi positif dan negatif. A kibat buruk yang harus mendapat perhatian khusus adalah: Digital Bullying, perbuatan salah atau kriminal, hiburan seksual, aspek komunikasi dan interaksi yang buruk, bahaya wacana penghinaan, gangguan emosional dan fisik anak, kecenderungan untuk mengungkap hal yang menjadi rahasia pribadi (Sunarto, 2017: 34). Kajian yang dilakukan oleh Yakob Godlif mengemukakan 
bahwa dampak negatif distrupsi teknologi terhadap perilaku sosial individu adalah: tidak tersaringnya informasi dari berbagai sumber sehingga menimbulkan pengambilan sikap berbeda terhadap suatu objek yang sama serta tersebbar nya berita palsu atau hoax, yang diidentikkan dengan isu Suku Agama Ras Antar Golongan (SARA) serta berita palus dalam aspek politik, pornografi, tindak kekerasan, kemudian mengabaikan penghormatan untuk berinteraksi melalui media berbasis web atau medsos, perkembangan istilah baru dalam aspek komunikasi sehingga melemahkan rasa hormat atau terabaikannya rasa memuliakan terhadap yang lebih tua serta lupa bagaimana cara berkomunikasi serta adab berinteraksi dengan orang yang lebih tua. A danya distrupsi teknologi juga berdampak pada melemahnya inetraksi secara tatap muka atau bersilaturahim langsung sehingga merenggangkan sebuah hubungan emosional (Malatuny et al., 2020: 67). Di sekolah, kasus pertikaian meningkat secara signifikan, dan kurangnya disiplin di sekolah (Johnson dan Johnson, 1996: 459-506). Di Indonesia, masalah serupa juga semakin banyak, seperti banyak pelanggaran, pencemaran nama baik, penggunaan obat-obatan terlarang. Dalam organisasi edukatif terjadi penurunan rasa percaya diri siswa, ketidakdisiplinan dan tidak adanya inspirasi serta motivasi untuk belajar. $\mathrm{H}$ al di atas merupakan beberapa dampak negatif dari adanya distrupsi teknologi ini, serta hal yang paling utama dalam aspek Pendiidikan Agama Islamm ialah berkaitan dengan perkembangan akhlak al karimah generasi muda islam, yang semakin hari semakin mengkhawatirkan.

Aspek akhlak dalam kajian kurikulum dan pembelajaran Pendidikan Agama Islam pada era distrupsi teknologi ini semakin menjadi sorottan. M engapa demikian? Karena dari hari ke hari generasi muda Islam semakin memperlihatkan sikap yang menjadi indikator merosotnya akhlak al karimah atau biasa disebut dengan demoralisasi. Hal ini dibuktikan dengan banyaknya generasi muda Islam yang sudah kecanduan bermain gadget serta penggunaaan aplikasi yang tidak berfaidah. Beberapa kaum hawa lebih senang berjoget ria di depan kamera dari pada untuk bermuta'la'ah terhadap sebuah materi pembelajaran. Sama halnya dengan kaum adam yang lebih mementingkan bermain game online, dari pada sholat berjamaah di masjid.

Sepanjang keberadaan perkembangan ilmu pengetahuan dalam Islam hingga Abad Pertengahan pada masa gemilang keagungan dan kejayaan peradaban Islam, tidak ada sekat serta tidak ada pemisahan antara ilmu pengetahuan dan ilmu agama. Peneliti mempelajari, menyelidiki dan membina kemampuan dirinya berdasarkan pada semangat untuk memuliakan orang-orang yang berpengetahuan. Semua ilmu yang bermanfaat bagi manusia pada dasarnya adalah ilmu pengetahuan yang bersumber dari Allah SWT yang harus dimanfaatkan 
(diaktualisasikan) sehingga dapat membantu sesama manusia. Itulah perwujudan kehadiran ilmu dalam ajaran Islam.

Pada saat itu tidak ada istilah untuk ilmu apapun dalam pandangan Islam, karena semua informasi dibawa ke dunia dari jiwa Islam mereka, baik itu bahasa, ilmu bawaan, atau figh. Bagaimanapun, setelah Abad Pertengahan akhir-akhir ini, mulai muncul kesepakatan bahwa harus ada penegasan bahwa ada sudut pandang "Islam" dari setiap ilmu yang diciptakan di dunia ini. Sampai saat ini, tampaknya polaritas ilmu yang ketat secara keseluruhan masih sangat mengesankan, meskipun fakta bahwa banyak perintis berusaha untuk menghapus dualisme sains dalam budaya Islam, itu sebenarnya menghabiskan sebagian besar hari untuk mencairkan kembali. dia. $\mathrm{H}$ al ini merepotkan mengingat fakta bahwa hal itu sangat sistematis baik dari segi kerangka kerja maupun budaya pada cakupan publik (Sehat Sultoni Dalimunthe, 2018: 24).

M isalnya, secara klasifikasisasi di Indonesia, masih ada istilah sekolah dan madrasah yang memiliki kerangka kelembagaan yang khas. Kelompok masyarakat menganggap bahwa madrasah adalah organisasi pendidikan formal yang memiliki sebagian besar ilmu agamanya, sedangkan sekolah adalah lembaga formal yang memiliki sedikit ilmu agama. Padahal secara etimologi, baik sekolah maupun madrasah memiliki makna yang sama yakni bermakna sekolah. Ketidakjelasan inilah yang justru menambah standarisasi dual isme dalam budaya I slam.

Kemudian dalam aspek sosio kutural, bahwa masyarakat lebih menggandrungi anak nya untuk dimasukan ke sekolah dari pada ke madrasah. Seakan-akan bahwa madrasah itu buangan dari peserta didik yang tidak diterima di sekolah. Dalam aspek tenaga pendidik, juga terdapat pemisahan. M isalnya bahwa guru Pendidiikan Agama I sllam yang mengajar di sekolah masuk data base dapodik kementrian Pendidikan nasional, harus masuk aplikasi emis dan aplikasi siaga atau system aplikasi guru agama. Sedangkan guru madrasah, tidak perlu masuk data base dapodik kementrian Pendidikan nasional, tapi cukup terdata dan memiliki akun simpatika dan emis saja. Sehingga dalam proses seleksi calon pegawai pemerintah dengan perjanjian kerja (PPPK) 2021, guru madrasah atau yang tidak terdata di dapodik kementrian Pendidikan dan kebudayaan, sehingga tidak bisa mendaftar seleksi Calon PPPK pada tahun 2021. Tentunya ini semakin menambah daftar hitam kurang profesionalnya pengelolaan system pendataan tenaga pendidik. Terutama guru Pendidikan Agama Islam. Baik, kita Kembali kepada isu tentang dualism ilmu pengetahuan.

U lama Islam tidak mengkambinghitamkan pada dualisme ini, dengan alasan terkadang terjadi penyimpangan dalam kemajuan ilmu pengetahuan yang bertentangan dengan nilai realitas yang diajarkan dalam Islam. Jadi inilah ide Islam bahwa harus ada keteguhan 
kepribadian Islam untuk sudut pandang ini agar umat Islam tidak menyimpang jauh dan terpecah (Sehat Sultoni D alimunthe, 2018: 25).

Adapun solusi yang ditawarkan oleh penulis, agar tidak terjadi pemisahan ilmu. M aka perlu memberikan penanaman atau internalisasi tentang paradigma wahyu memandu ilmu kepada guru dan siswa serta seluruh steakholder Pendidikan. Adapun paradigma wahyu memandu ilmu, ialah sebuah konsep bahwa semua ilmu bersumber dari Allah SWT, maka tidak perlu ada dikotomi ilmu.

Evaluasi merupakan salah satu komponen penting dalam rencana pendidikan untuk mengukur pencapaian tujuan rencana pendidikan yang ideal. Selanjutnya, jika evaluasinya offbase, sangat mungkin ditentukan bahwa target yang diatur dalam pembelajaran tidak tercapai. Evaluasi di sekolah Islam tentunya bukan hanya sekedar pencapaian kualitas kuantitatif dengan kemampuan untuk mengisi berbagai pertanyaan atau berbagai pertanyaan dalam keputusan yang berbeda. Evaluasi jenis tes ini secara umum akan mensurvei kapasitas pendalaman atau informasi tentang sekolah Islam yang ketat. Sementara itu, sekolah Islam sudut pandang informasi yang ideal, tetapi juga bagaimana perilaku ketat seseorang setelah memperoleh informasi ini. Selanjutnya, untuk memperoleh penilaian yang kredibel, diperlukan pendekatan penilaian yang berbeda bagi siswa yang terpisah dari penilaian tes, termasuk persepsi atau persepsi.

Salah satu kelemahan nyata dari Pendidikan agama Islam adalah bahwa ia kaya dalam ide-ide kunci yang fungsional atau ujian hipotetis, namun miskin dalam dimensi praksis atau operasionalnya atau ssebalaiknya, kaya akan ranah praksis atau operasional tetapi lepas kontrol dari ide atau konsep dasarnya, sehingga terjadi gap di lapangan. Untuk mencegah terjadinya ketidaksinkronan antara konsep dan praktik, maka sallah satu pendekatan yang dapat dilakukan adalah dengan mencari ide-ide filosofis seputar pendidiikan Islam ( M ahfud, 2018: 86).

\section{Reorientasi Kurikulum dan Pembelajaran Pendidikan Agama Islam}

Islam adalah agama yang ideal, ajaran Islam serta Rasulullah Muhammad Shollallo'hu alaihi wasallam diutus ialah untuk menyempurnakan akhlak dan menyebarkan Islam yang penuh kasih sayang bagi alam seluruh alam. D engan demikian maka tujuan Pendidikan A gama Islam harus berorientasi pada proses pembinaan akhlak al karimah serta pola pembinaan pada peserta didik yang harus lebih humanis. Sehingga Pengajaran Pendidiikan agama Isllam bukan hanya tentang transfer pengetahuan tentang Islam saja (Ahmad Tafsir, 1994: 34). T api, kurikulum Pendidikan Agama Islam juga harus untuk mampu membina dan membentuk 
keyakinan Islam yang kokoh, membentuk orang yang mulia dan orang yang hebat, melahirkan siswa yang sehat, memiliki pengetahuan, kemampuan, dan keterampilan tertentu dalam diri seseorang sehingga terlahirlah insan kamil yang memiliki pengetahuan tinggi dan berakhlak sufi.

Kemudian, Pengajaran Islam tidak hanya diidentikkan dengan bagaimana individu mengetahui ilmu tentang agama dan kapasitas agama, namun juga perlu adanya perubahan perilaku yang tegas terhadap pelaksanaan atau pengamalan baik dalam diri, keluarga, maupun kehidupan masyarakat setempat. Pada akhirnya Pendidikan agama Isllam akan mewujudkan masyarakat umum yang memiliki peradadaban tinggi yang tercermin dalam istilah baldatun thoyyibatun warbbun ghafur yakni negeri yang baik serta diampuni dan diridhoi oleh Allah subhanahu wata'aala.

Sebagaimana dijelaskan oleh imam al-G hazali yang dikutip oleh Fathiyah Sulaeman, substansi kurikulum pendidikan Islam memiliki hal atau urutan yang harus diutamakan dan urutan isi ini harus diutamakan serta dipertimbangkan dalam kerangka kurikulum dan pengajaran Islam (Fathiyah Sulaeman, 2015: 22). Adapun urutan kurikulum yang dimaksud ialah sebagai berikut:

Pertama; Al-Q uran dan as-Sunnah, sebagai basis dalam isi kurikulum Pendidikan Islam. Lalu kemudian ada tafsir, hadits, figh serta T arikh atau sejarah. Berkonsentrasi pada A IQur'an dan Sunnah menempati posisi pertama dan utama dalam ajaran Islam dengan alasan bahwa sebelum mempelajari ilmu apapun, seorang M uslim harus terlebih dahulu menguasai, memahami dan mampu mengamalkan Al-Q ur'an dan Sunnah sebagai pengaturan dasar dan pertama dalam melakukan kewajibannya sebagai dalam menjalankan tugas sebagai $K$ halifah fil ard dan Abdullah.

Kedua, kajian bahasa (Arab), nahwu, shorof, fiqih, lugah. U rutan kedua adalah berkiatan dengan Bahasa arab, karena ilmu ini merupakan alat pembuka dalam belajar al quran dan hadis $\mathrm{N}$ abi, juga karena AI-Q ur'an diturunkan dalam bahasa Arab, dan sebagian besar ilmu $H$ adiis serta kitab klasik atau salaf karya para ulama ditulis dalam sumber utamanya dalam bahasa Arab. Ketiga, ilmu-ilmu yang termasuk pada mata pelajaran wajib kifayah, seperti faraid, tajwid, kedokterana atau Kesehatan dzhoir, matematika dan berbagai kemampuan, termasuk syiasah (masalah pemerintahan). Keempat, ilmu-ilmu social budaya seperti syair, menulis, sejarah, filsafat islam,, matematika, penalaran, ilmu politik dan moral.

Sebagai sistem dalam kurikulum Pendidikan Islam terdiri dari empat komponen yakni tujuan, isi, strategi, dan penilaian. Bagian utama dari program pendidikan adalah tujuan. Selain 
itu, Islam berfokus pada tujuan yang ingin dicapai secara jelas. Tujuan mendasar dari Pendidikan Islam adalah untuk membentuk individu M uslim yang sempuurna ( Insan Kamil). $\mathrm{H}$ arus mampu memahami entitas dirinya sebagai makhluk dua dimensi yakni dimensi wakil Tuhan di muka bumi ( $k$ halifah fil ard) dan hamba Allah yang harus senantiasa beribadah padaNya (Abdullah) (Kiki M ayasaroh, 2020: 77-88).

Strategi memainkan peran penting dalam menyampaikan materi untuk muncul pada tujuan instruktif yang ideal. Sehebat apapun tujuannya, sehebat apapun materinya, jika tidak menggunakan strategi dan metode yang tepat, objektif dan bagusnya materi hanyalah sebuah asal usul. O leh karena itu, strategi yang tepat dalam mencapai tujuan pembelajaran harus selalu diupdate kembali sesuai dengan kebutuhan dan perkembangan zaman. $\mathrm{H}$ ambatan bagi guru Pendidikan agama Islam yang tegas dalam menyampaikan materi untuk mencapai tujuan tersebut adalah tidak adanya inovasi dalam memilih strategi yang tepat. Guru PAI pada umumnya akan menggunakan strategi adat lama dalam menyampaikan materi agama yaitu ceramah (Abudin N ata, 2017: 31).

Menurut penulis, metode pembelajaran Pendidikan Agama Islam harus bervariasi tergantung dari sarana sekolah, materi dan kondisi psikologis peserta didik. N amun yang paling diutamakan dalam penerapan suatu metode penelitian ialah tergantung dari materi yang akan disampaikan. M isalnya, jika materi Pendidikan agama islam tentang pengurusan jenazah, maka perlu menerapkan metode demonstrasi atau praktik. Kemudian jika materi tentang munakahat maka perlu metode role playing. Jika tentang sejarah maka harus menggunakan metode tanya jawab dan kisah yang inspiratif. Serta lain sebagainya, setiap metode yang akan mengkonstuk pola pikir peserta didik. Sehingga jika metode pembelajaran peserta didik bervariasi, maka tidak akan terjadi misunderstanding dan disorientasi.

Saat ini dunia telah memasuki era industri 4.0, kemudian akan masuk era society 5.0 maka Kembali ditegaskan bahwa metodologi dan strategi pembelajaran Pendidikan Agama Islam harus mampu menyesuaikan dengan kemajuan ilmu pengetahuan dan inovasi serta teknologi tersebut. Spesialis komputer dan pemrograman mendorong berbagai macam kegunaan dan kemajuan sebuah aplikasi serta teknologi untuk Pendidikan secara umum. Ini jelas harus diikuti oleh para ahli Pendidikan agama Islam yang. Karena, jika tidak mampu beradaptasi atau tidak dapat menyesuaikan. Maka Pendidikan agama isllam akan tertinggal oleh Pendidikan lainnya (Kambali, 2018: 17-30).

Karena dunia sudah memasuki era digitalisasi, maka metode pembelajaran serta penggunaan media pembelajaran juga harus modern. Misalnya menerapkan strategi dan metode pembelajaran tanya jawab dengan berbantukan media audio visual. Kemudian ada quiz 
dengan menggunakan aplikasi berbasis android seperti kahoot, quizziz dan lain-lain. Sehingga peserta didik merasa tergugah dan termotivasi untuk belajar. Karena menggunakan metode dan media pembelajaran yang modern diera digital ini.

\section{Simpulan}

Pendidikan Agama Islam selalu menghadapi dinamika yang beragam. Dalam tataran aktual hal itu mempunyai potensi tantangan dalam setiap elemennya. M engetahui dinamika yang terjadi di dunia pendidikan Islam sekaligus alternatif solusinya, maka seyogianya ummat M uslim selalu mempertimbangkan perspektif insider dan outsider sehingga tidak serta merta membenarkan informasi yang diterima tetapi kita harus mempunyai peran sebagai pengamat penuh (complete observer), pengamat sekaligus sebagai pelaku (observer as participant), pelaku tapi sebatas sebagai pengamat ( participant as observer), atau pelaku penuh (complete participant) untuk meluruskan informasi yang sebenarnya. Penyelesaian problem solving yang didasarkan pada insider dan outsider dengan titik fokus tersebut dapat diorientasikan pada tataran teologis (iman), teoretis (ilmu), praktis (amal) dan moralistis (akhlak) sehigga mampu menciptakan keunggulan (ciri khas) yang didapat dari sisi kelemahannya masing-masing tersebut untuk dikembangkan menjadi ciri khasnya lembaga pendidikan Islam tersebut sehingga mampu bersaing dengan lembaga pendidikan lainnya.

\section{DAFTAR PUSTAKA}

Abdul M ujib, Abdul M ujib, and Jusuf M udzakkir. (2007), IImu Pendidikan Islam. Kencana Prenada M edia Group.

Abudinn N ata. (2017), IImu Pendidikan Islam,

Ahmad Izzan., Saehudin. (2018). H adis Pendidikan: Konsep Pendidikan Berbasis H adis -, 2016. Dalimunthe, Sehat Sultoni. O ntologi Pendidikan Islam: Mengupas Hakikat Pendidikan Islam D ari Konsep ... - Sehat Sultoni D alimunthe - Google Buku.

Amiruddin, A. (2021). U rgensi pendidikan akhlak : tinjauan atas nilai dan metode perspektif islam di era disrupsi. J ournal of Islamic Education Policy, 6(1), 1-19.

Angelina, P., Kartadinata, S., \& Budiman, N. (2021). Kompetensi pedagogis guru di era disrupsi pendidikan dalam pandangan Islam. Ta'dibuna: Jurnal Pendidikan Islam, 10(2), 305. https:// doi.org/ 10.32832/ tadibuna.v10i2.4863

Arifin, S. (2019). Disrupsi dan Persoalan "Karakterisasi" Dalam Pendidikan di Era Digital. Seminar N asional Bahasa D an Sastra, 3(2018), 17-20.

Baidlawi, H. M. (2003). M O DERN ISASI PEN DIDIKAN ISLAM ( Telaah Atas Pembaharuan 
Pendidikan di Pesantren) H. M oh. Baidlawi. T adris, 1(2) , 155-167.

Drajat, M . (2020). Re-O rientasi Kurikulum Pendidikan Islam. Al-Afkar, Journal For Islamic $\begin{array}{llll}\text { Studies, } & 3(2 & \text { SE- }), & 172-185 .\end{array}$ https:// alafkar.com/ index.php/_Afkar_Journal/ article/ view/ 130

D rajat, M . (2020). Re-O rientasi Kurikulum Pendidikan Islam. Al-Afkar, Journal For Islamic $\begin{array}{llll}\text { Studies, } & 3(2 & \text { SE- }), & \text { 172-185. }\end{array}$ afkar.com/ index.php/ Afkar__ournal/ article/ view/ 130

Fajrin, S. (n.d.) . Reorientasi Pendidikan Islam Tradisional di Indonesia. 2(2) , 41-52.

Fikri, A. (2019). Pengaruh Globalisasi dan Era Disrupsi terhadap Pendidikan dan N ilai-N ilai Keislaman. Sukma: Jurnal Pendidikan, 3(1), 117-136. https:// doi.org/ 10.32533/03106.2019

Helaluddin, H. (2018). Redesain Kurikulum Pendidikan Tinggi Islam: Strategi Dalam Menyongsong Era Revolusi Industri 4.0. Jurnal MUDARRISUNA: Media Kajian Pendidikan Agama Islam, 8(2) , 258. https:/ / doi.org/ 10.22373/ jm.v8i2.3224

H endri, H . I., \& Firdaus, K. B. (2021). Resiliensi Pancasila Di Era Disrupsi: Dilematis M edia Sosial D alam M enjawab T antangan I su Intoleransi. Jurnal Paris Langkis, 1(2) , 36_47.

Islam, M. P. (2018). REORIENTASI DINAMIKA PENDIDIKAN ISLAM Akhsin Ridho IAIN Jember. 1.

Juliayanto, W., Auliya, H., \& Rubiyad, A. (2021). Konsep Pendidikan Islam M enurut KH. Yahya $M$ asduqi. M asile, 1(1) , 240-262.

Kartini, K., \& Istiana, L. (2020). Reformasi Madrasah Pada Era Disrupsi: Peran Pandemik Covid-19 Dalam Pendidikan Teknologi. Paedagoria: Jurnal Kajian, Penelitian Dan ..., 11(2) , 208-212. https:// core.ac.uk/ download/ pdf/ 327096991.pdf

Khulusinniyah, K., \& Wassalwa, A. (2017). Reorientasi N ilai-nilai Kepesantrenan Pada "Santri Kalong" Pondok Pesantren Salafiyah Syafi'iyah Sukorejo. Jurnal Pendidikan Islam Indonesia, 1(2) , 237-249. https:/ / doi.org/ 10.35316/ jpii.v1i2.52

Lubis, M ., Yusri, D ., \& Gusman, M . (2020). Pembelajaran Pendidikan Agama Islam Berbasis E-Learning (Studi Inovasi Pendidik MTS. PAI Medan di Tengah Wabah Covid-19). Fitrah: Journal of Islamic Education, 1(1) , 1-18. https:/ / doi.org/ 10.53802/ fitrah.v1i1.1

METHODS IN ISLAMIC EDUCATION LEARNING." Risâlah, Jurnal Pendidikan Dan Studi Islam 5, no. 2, Sept (2019): 60-75.

Prasetia, S. A., \& Fahmi, M . (2020). Reorientasi, Peran dan T antangan Pendidikan Islam di tengah Pandemi. T arbawi, 9( 1) , 21-38. https:// doi.org/ 10.36781/ tarbawi.v9i1.3128

Prasetia, S. A., \& Fahmi, M . (2020). Reorientasi, Peran dan Tantangan Pendidikan Islam di tengah Pandemi. T arbawi, 9( 1) , 21-38. https:/ / doi.org/ 10.36781/ tarbawi.v9i1.3128 
Rahmawati, F. (2018). Kecenderungan Pergeseran Pendidikan Agama I slam di Indonesia Pada Era Disrupsi. TADRIS: Jurnal Pendidikan Islam, 13(2). https:/ / doi.org/ 10.19105/ tjpi.v13i2.1752

Rosyad, Ali Miftakhu. "Implementasi Pendidikan Karakter Dalam Pembelajaran Pendidikan Agama Islam Di Sekolah M uhammadiyah Se-Kabupaten Indramayu. Al-Afkar." Journal for Islamic Studies 4 ( n.d.).

Samsudin, S. (2019). Peran Pendidikan Agama Islam dalam M embentuk Kepribadian di Era Disrupsi. Jurnal Pemikiran Keislaman, 30(1), 148-165. https:/ / doi.org/ 10.33367/ tribakti.v30i1.666

Samsudin. (2019). Tantangan Lembaga Pendidikan Pesantren Di Era Disrupsi. Proceeding Conference on Islamic Studies (ColS) 2019, 221-230.

Santosa, S. (2021). Urgensi Peran Orang Tua Membangun Kepemimpinan Anak di Era Disrupsi Teknologi Berdasarkan Ulangan 6: 6-9. EDULEAD: Journal of Christian Education and Leadership, 2(1) , 71-88. https:// doi.org/ 10.47530/ edulead.v2i1.61

Sayyidi, S., \& Sidiq, M. A. H. (2020). Reaktualisasi Pendidikan Karakter di Era Disrupsi. Bidayatuna: Jurnal Pendidikan Guru Mandrasah Ibtidaiyah, 3(1), 105. https:/ / doi.org/ 10.36835/ bidayatuna.v3i01.520

Syábani, M. A. Y. (2018). Pengembangan Kurikulum Pendidikan Agama Islam Dalam Perspektif Pendidikan Nilai. Tamaddun, 19(2), 101. https:/ / doi.org/ 10.30587/ tamaddun.v0i0.699

T saniyah, N ., \& Juliana, K . A. (2019) . Literasi Digital Sebagai U paya M enangkal H oaks Di Era Disrupsi. Al-Balagh: Jurnal Dakwah Dan Komunikasi, 4(1), 121. https:/ / doi.org/ 10.22515/ balagh.v4i1.1555 
